University of California, Hastings College of the Law UC Hastings Scholarship Repository

Faculty Scholarship

1985

\title{
Indigenous Peoples, Land Claims and Control of Mineral Development: Australian and U.S. Legal Systems Compared
}

John D. Leshy

UC Hastings College of the Law, leshyj@uchastings.edu

Follow this and additional works at: http://repository.uchastings.edu/faculty_scholarship

Part of the Oil, Gas, and Mineral Law Commons

\section{Recommended Citation}

John D. Leshy, Indigenous Peoples, Land Claims and Control of Mineral Development: Australian and U.S. Legal Systems Compared, 8 New S. Wales L.J. 271 (1985).

Available at: http://repository.uchastings.edu/faculty_scholarship/389 


\section{Faculty Publications \\ UC Hastings College of the Law Library}

Author: John D. Leshy

Source: $\quad$ University of New South Wales Law Journal

Citation: $\quad 8$ U. New S. Wales L.J. 271 (1985).

Title: $\quad$ Indigenous Peoples, Land Claims and Control of Mineral Development: Australian and U.S. Legal Systems Compared

Originally published in UNIVERSITY OF NEW SOUTH WALES LAW JOURNAL. Reprinted with permission from UNIVERSITY OF NEW SOUTH WALES LAW JOURNAL and University of New South Wales School of Law. Free access is also available through Austlii, http://www.austlii.edu.au/au/journals/UNSWLawJl/1985/20.html. 


\title{
INDIGENOUS PEOPLES, LAND CLAIMS, AND CONTROL OF MINERAL DEVELOPMENT: AUSTRALIAN AND U.S. LEGAL SYSTEMS COMPARED
}

\author{
JOHN D. LESHY*
}

\section{INTRODUCTION}

Some legal principles expose more sharply than others the underlying values of the society in which they apply. An example of a relatively sharp reflection is the legal right to control mining activity on one's land. Any legal system that recognises private rights in land must confront the question of what kind of control to give the landowner over exploration and development of the land's mineral resources. The basic models are, on the one hand, giving the landowner ownership and full control over mineral activity; and on the other, giving ownership and control to the government and/or the miner, rather than the landowner. Between these polar positions stretches a continuum where more or less emphasis is placed on the respective rights of the landowner and the government or miner.

Charting a course in this area involves value-laden judgments about the degree to which mining should be encouraged and other uses of the land protected. Mineral development can produce important financial revenues and be a mainspring of the economy. In Western Australia, for example, mineral development is now by most conventional forms of economic measurement considerably more important than other rural, so-called primary industries, a reversal of the comparative

* B.A. (Harvard College) J.D. (Harvard Law School) Robinson Cox Visiting Fellow, U.W.A. Law School, 1985; Professor of Law, Arizona State University Tempe, Arizona, U.S.A.

The views expressed herein are solely those of the author. 
rankings of a couple of decades ago. ${ }^{1}$ Also, mineral development tends to bring concentrated social and environmental change to areas it directly affects. From the landowner's perspective, the ability to exert power over mining on one's land also promotes the values of autonomy and dignity.

When the land involved is claimed or controlled by indigenous peoples, these concerns tend to be magnified. Indigenous populations in Australia and the United States, now numerically a small minority, tend to have severe economic disadvantages, a sensitivity to social and environmental change, and a pronounced sense of powerlessness. In these circumstances, mineral development is a two-edged sword - it can offer material benefit while at the same time posing threats to the social structure and land areas of cultural importance to these peoples, threats that may be more acute the more traditional the culture. ${ }^{2}$ In more remote parts of Australia, for example, mineral activity has recently been described as supplanting missions, pastoralists and government as the major point of contact between Aborigines and nonAborigines. ${ }^{3}$

It is not surprising, then, that the most contentious single feature of the general question of land rights for Aborigines in Australia is their right to control mineral development.

Like the other Australian states and the Commonwealth, Western Australia has recently confronted this issue. ${ }^{4}$ Debate has been lively and the matter remains unsettled. The purpose of this paper is to compare Aboriginal rights vis-a-vis mineral development in Australia, especially Western Australia, with the experience of indigenous peoples in the United States - the American Indians.

Within the confines of the general topic, I will paint with a rather broad brush. For example, I will address only tangentially the overriding question of whether, how much, and by what process lands or interests in lands ought to be set aside for Aboriginal communities. I will not explore details such as at what stage(s) in the process of exploring for, identifying and producing minerals might Aboriginal consent be appropriate, how representatives of Aboriginal interests might be selected, or indeed how Aborigines themselves may be defined or identified. Finally, I will not address what might ultimately prove to

1 See Gordon Jackson, "The Australian Economy" in S.R. Graubard (ed.), Australia: The Daedalus Symposium (1985) 232-233; Michael W. Hunt \& Michael A. Lewis, Mining Law in Western Australia: A Guide (1983) 1. See also Andrew G. Lang \& Michael Crommelin, Australian Mining and Petroleum Laws: An Introduction (1979) 7.

2 David Cousins \& John Nieuwenhuysen, Aboriginals and the Mining Industry: Case Studies of the Australian Experience (1984). For a somewhat different perspective, see Janine Roberts, Massacres to Mining: The Colonisation of Aboriginal Australia (1981).

3 Daniel Vachon \& Phillip Toyne, "Mining and the Challenge of Land Rights" in N. Peterson \& M. Langton (eds), Aborigines, Land and Land Rights (1983) 307.

4 See generally Paul Seaman Q.C., The Aboriginal Land Inquiry (Report to Western Australia Minister with Special Responsibility for Aboriginal Affairs, 1984). 
be the most important practical issue - the extent to which existing mineral licences or permits are 'grandfathered' or insulated from any new control mechanisms that may accompany recognition of Aboriginal land rights. ${ }^{5}$

\section{AMERICAN INDIANS AND MINERAL OWNERSHIP AND DEVELOPMENT}

\section{Overview}

Indians in the United States today generally control the development of mineral resources on their lands. The tribes are considered beneficial owners of the minerals, collectively representing the interests of their members, though the United States holds legal title in trust for each tribe.

The terms of mineral development are set partly by federal statute and partly by negotiations between the tribe and the mineral developer, with the federal government as trustee an obviously interested participant. For the most part, federal statutes or regulations ${ }^{6}$ establish minimum standards, and the tribe may negotiate upwards from them to secure greater protection for the environment, more employment opportunities for its members, and other benefits. The crucial financial terms, the rental and royalty rates, are mostly established by negotiation, with the market-place and the tribe's veto power exerting important influences.

Two relatively recent developments have given tribes additional leverage over mineral developers and greater control over mineral development. First, the United States Supreme Court has lately confirmed that tribes exercise not only considerable proprietary power over mineral development, but also sovereign powers, such as the right to tax and otherwise regulate the activities of mineral developers found within their jurisdiction. ${ }^{7}$ Second, the United States Congress has given tribes considerably more flexibility in dealing with mineral developers, including authority to enter more participatory arrangements like joint ventures and operating agreements. ${ }^{8}$

5 On these issues, see generally ibid., and John L. Toohey, Seven Years On: Report on the Aboriginal Land Rights (Northern Territory) Act 1976 and Related Matters (1984).

6 The principal statute is the Indian Mineral Leasing Act of 1938, 25 U.S.C. § $396 \mathrm{a}-\mathrm{g}$, though there are numerous special statutes of more limited applicability. See generally Felix $S$. Cohen's Handbook of Federal Indian Law (1982) 533-536 (hereinafter Cohen's Handbook). The applicable regulations are found at 25 Code of Federal Regulations Subchapter I, Parts 211-227.

7 Merrion v. Jicarilla Apache Tribe 455 US 130 (1982); Kerr-McGee v. Navajo Tribe 85 L Ed 2d 200 (1985).

8 Indian Mineral Development Act of 1982, 25 U.S.C. § 2101-2109. 


\section{History}

Though it is relatively easy to describe the current legal structure governing mineral development on Indian lands, the evolution of that structure has been complex. The logical starting point is the national government's traditional recognition that its dealings with Indians are on a sovereign-to-sovereign basis. But though the tribes have inherent sovereignty over their members and resources, this sovereignty is not equivalent to the sovereignty of the national government. Rather, it is a sovereignty dependent upon the wisdom and goodwill of the dominant national government. Indian tribes are, in John Marshall's words, "domestic dependent nations". 9 Their sovereignty may be extinguished by Congress, and their property, like that belonging to all others, may be taken by resumption (the exercise of eminent domain) for public purposes upon payment of just compensation, even when the United States had previously agreed by treaty to "secure" the land involved to the Indians "forever". ${ }^{\circ}$ For the most part, however, the tribes' legal right to occupy and control activities on their traditional lands has been unquestioned.

Though the existence of inherent Indian sovereignty was confirmed relatively early in opinions of Chief Justice Marshall for the United States Supreme Court, ${ }^{11}$ these opinions merely ratified what had been acknowledged in practice almost from the beginning of European/Indian contact. This practice was conceptually grounded in contemporary principles of international law influentially espoused by de Vattel, among others. ${ }^{12}$

The major ambiguity left by Marshall's opinions was whether the government could extinguish an Indian tribe's rights to land it had traditionally occupied without payment of compensation. In an early opinion, Marshall hinted that it could, by saying that Indian customary or "original" title, as it has come to be known, can be extinguished by purchase or by conquest. ${ }^{13}$ For well over a century after this, however, the Court had no occasion to pursue the question of when a conquest actually existed. The reasons for the delay, and the eventual resolution, will be pursued further below.

Another important, though subsidiary, proposition established rather early on in the American experience was that the national government had a monopoly on dealings with Indians. This monopoly found expression in the "Indian commerce clause" in the United States Constitution, in statutes enacted by the very first Congress that survive to the present day, as well as in opinions by Chief Justice Marshall for

9 The Cherokee Nation v. The State of Georgia 30 US (5 Pet) 1, 16 (1835).

10 See Federal Power Commission v. Tuscarora Indian Nation 362 US 99, 115, 136 (1960); Cohen's Handbook, note 6 supra, 521-522.

11 Cohen's Handbook, note 6 supra 233-235.

12 Id., 50-58, 233-234.

13 Johnson v. McIntosh 21 US (8 Wheat) 543, 587 (1823). 
the Supreme Court. ${ }^{14}$ So much importance attached to this principle that in recent years the courts have voided several land transactions between Indians and states, most of them many decades old, that were executed without the express approval of the national government. ${ }^{15}$ The net effect is that, generally speaking, state governments can exercise authority over Indian tribes and territory only to the extent that the national government explicitly permits it.

The combined effect of these two principles has been, simply stated, that Indian tribes retained control of their people and the geographic areas they had traditionally occupied until the national government dispossessed them by some lawful arrangement, usually a treaty or agreement embodied in a statute or presidential order. Dispossession of course proceeded apace over many decades, until today Indian tribes collectively control about 50 million acres ( 20 million hectares), or somewhat less than $2 \%$ of the total area of the United States. ${ }^{16}$

It is important to recognise, however - despite the John Wayne image of the conquest of the American West, and despite the fact that the courts had not definitively required compensation for the taking of original Indian title - that the national government gererally compensated the Indians for these lands. A leading authority on American Indian law, Felix Cohen, described the process this way in 1947:

[T]he historic fact is that practically all of the real estate acquired by the United States since 1776 was purchased not from Napoleon or any other emperor or czar but from its original Indian owners. What we acquired from [foreign sovereigns] ... was not the land ... but simply the power to govern and to tax... It may help us to appreciate the distinction between a sale of land and the transfer of governmental power if we note that after paying Napoleon 15 million dollars for the cession of political authority over the Louisiana Territory we proceeded to pay the Indian tribes of the ceded territory more than twenty times this sum for such lands in their possession as they were willing to sell. And while Napoleon, when he took his 15 million dollars, was thoroughly and completely relieved of all connections with the Territory, the Indian tribes were wise enough to reserve from their cessions sufficient land to bring them a current income that exceeds each year the amount of our payment to Napoleon... While nobody has ever calculated the total sum paid by the United States to Indian Tribes as consideration for more than two million square miles of land purchased from them, and any such calculation would have to take account of the conjectural value of a myriad of commodities, special services, and tax exemptions, which commonly took the place of cash, a conservative estimate would put the total

14 See e.g. Worcester v. The State of Georgia 31 US (6 Pet) 515 (1832). Unlike the other states in the Union, those states comprising the thirteen original colonies have, as direct successors in interest to the 'discoverer' European nation, fee title to Indian land; Oneida Indian Nation v. County of Oneida 414 US 661, 670 (1974). Nevertheless, even these states cannot extinguish Indian land claims without federal consent.

15 See e.g. County of Oneida v. Oneida Indian Nation 105 S Ct 1245 (1985); R. Clinton and M. Hotopp, "Judicial Enforcement of the Federal Restraints on Alienation of Indian Land: The Origins of the Eastdern Land Claims" (1979) 31 Maine L Rev 17-90.

16 Cohen's Handbook, note 6 supra, 471-472. 
price of Indian lands sold to the United States at a figure somewhat in excess of 800 million dollars. ${ }^{17}$

The Indian reservations that remained were generally assumed to encompass minerals as well as land. Indeed the reservations that comprise nearly all tribal lands today were often not originally reservations made by the national government for the benefit of Indian tribes, but rather reservations made by the tribes themselves as part of transactions in which they yielded their interest in other lands to the national government. ${ }^{18}$ Almost none of these transactions ever expressly mentioned mineral rights. ${ }^{19}$ But because the Indians were reserving lands for themselves, it was easy to conclude that they had also reserved the mineral rights; that is, it was the relinquishing of these rights that would have required some explicit reference. Similarly, when the national government on its side acknowledged the Indians' right of absolute, undisturbed possession of particular lands without reference to minerals, it was easy to conclude that the Indians' interest in these reserved lands included mineral rights.

The Supreme Court did not actually confirm that tribes owned minerals on their reservations until the Shoshone case in $1938,{ }^{20}$ after almost all the reservations had assumed their current dimensions. This result had been, however, thoroughly anticipated by decades of practice and congressional legislation. ${ }^{21}$ The only remarkable thing about the case was that the national government parsimoniously argued against tribal ownership of minerals. Only one of the seven sitting Justices, former Solicitor General Reed, dissented, without opinion. ${ }^{22}$

The result reached in Shoshone was fully consistent with the common law notion that, absent explicit arrangements to the contrary, the owner of land also owns everything on or below the surface, including minerals. Thus in a companion case, the Court also decided that Indian tribes owned standing timber on their reservations. ${ }^{23}$ Three decades earlier, in fact, the Court had determined that tribes owned water found on their reservations to the extent it was needed to fulfil the purpose of the reservation. Though this decision, in the Winters case, ${ }^{24}$ has proved highly controversial in recent times, it has not been because it recognised tribal ownership of water, but rather because it did so in terms inconsistent with the then prevailing common law view of water rights adopted by the states. Not only that, but Winters involved a fugitive resource subject to interdependent use, and a significant new

17 F. Cohen, “Original Indian Title” (1947) 32 Minn L Rev 28, 35-36.

18 Id., 35.

19 Cohen's Handbook, note 6 supra, 532 n. 33 and accompanying text.

20 United States v. Shoshone Tribe 304 US 111 (1938).

21 For example, the first statute authorising Indians to develop minerals on their lands was enacted in 1891. See Cohen's Handbook, note 6 supra, 533.

22 As Solicitor-General, Reed had earlier argued against the tribe's claim for compensation. See Shoshone Tribe v. United States 299 US 476,481,483-484 (1937).

23 United States v. Klamath Indians 304 US 119 (1938).

24 Winters v. United States 207 US 564 (1908). 
federal intrusion into state law (water found on national government lands, unlike minerals, having traditionally been governed mostly by state law).

Even if Indian reservations were to be perceived as grants by the government to Indians, rather than reservations by the Indians for themselves, it was still consistent with the policy then prevailing to regard Indian reservations as embracing minerals as well as land. That is, nearly all of the Indian reservations were created during the period when the policy of the national government was generally not to separate mineral from other rights in land. For the first twelve decades of the country's existence, the government's decision to convey land into non-federal ownership was a decision to convey in fee simple, mineral rights included. Though the government generally reserved lands it knew were valuable for minerals when it conveyed lands to railroads, homesteaders, and others, it nevertheless conveyed mineral rights with all other rights when it decided to dispose of particular parcels. It was not until the early part of the twentieth century, after the boundaries of most Indian reservations had been fixed, that the government began to reserve the mineral rights for itself while conveying the remainder of the fee. ${ }^{25}$ The earlier practice to convey full fee title thus also justified recognising Indian rights in the minerals on their reservations, although it was not mentioned in the Court's opinion in Shoshone.

This is not to say that Indian property rights in the minerals were always fairly dealt with by the national government, or that the Indian interests were always carefully preserved. To the contrary, some of the darker chapters in Indian-white relations in American history were sparked by conflicts relating to minerals. The controversy giving rise to two of John Marshall's seminal opinions in Indian law in the 1830s had been exacerbated by the discovery of gold on Cherokee land in Georgia. ${ }^{26} \mathrm{~A}$ few years later, the discovery of gold in the foothills of the Sierra Nevada in California set the stage for the displacement (and in several cases extermination) of some California Indians with the tacit acquiescence of the national government. Those Indians who survived were left with small reservations in what was actually the beginning of the reservation system. Nevertheless, as Felix Cohen noted nearly a century later, many of these California tribes eventually received compensation for their lost lands. ${ }^{27}$ The most well-known event in

25 See e.g. Watt v. Western Nuclear 462 US 36 (1983); Robert K. Swenson, "Legal Aspects of Mineral Resources Exploitation" in Paul W. Gates (ed.), History of Public Land Law Development (1968) 700-719; Loren L. Mall, "Federal Mineral Reservations" (1975) X Land \& Water L Rev 1 .

26 See Joseph C. Burke, "The Cherokee Cases: A Study in Law, Politics and Morality" (1969) 21 Stan L Rev 500, 503; see also Francis Paul Prucha, American Indian Policy in the Formative Years (1962) 178-182 (describing the loss of Indian lands in Wisconsin because of mining pressure between 1827 and 1833).

27 Note 17 supra, 36-37. 
American Indian-white relations, the extermination of the Seventh Cavalry under General Custer in 1876, had its origins in the discovery of gold on Sioux lands in the Black Hills. ${ }^{28}$ The inevitable result: dispossession of the Indians and formal opening of the lands to white miners.

However in nearly all these situations, the Indians were eventually compensated for the lands, including minerals, they lost. Whether such compensation was just is another question, one that could, as Felix Cohen pointed out, be debated inconclusively forever. ${ }^{29}$ But the national government eventually subjected the adequacy of its compensation in such cases to judicial review. In 1980, for example, the United States Supreme Court upheld an award of damages, with interest, to redress the Sioux Tribe for the inadequate compensation it had received when the Black Hills were wrested from it after Custer's defeat 104 years earlier. ${ }^{30}$

The system of recognition of Indian mineral rights and compensation for any divestiture has concededly not been perfect. Though Cohen's analysis, first published in 1947, has survived for the most part intact, he did not anticipate a reversal by the Supreme Court of its previous position on one point - whether the national government owed compensation for the extinguishment of "unrecognized" Indian title to lands; that is, lands traditionally occupied by Indians but whose rightful occupation the United States had never specifically, formally acknowledged.

In 1955, the United States Supreme Court decided in the Tee-Hit-Ton case that the government need not compensate Indians in such circumstances. ${ }^{31}$ Cohen's failure to anticipate this decision was understandable, because a plurality of four Justices had, in the Alcea $B$ Band case, decided nine years earlier (the year before Cohen's article was published) squarely held that a taking of original or unrecognised title required redress: "[t]he Indians have more than a merely moral claim for compensation." 32 A fifth Justice, Hugo Black, had concluded that regardless of how that question might be decided, Congress had specifically assumed the obligation to pay for takings of original Indian title in the same statute in which it had waived the government's sovereign immunity from suit. Three Justices had dissented from the conclusion that extinguishment of the Indian occupancy required compensation. The dissent had worried openly about the magnitude of

28 Evan Connell, Son of the Morning Star (1984) 237-241.

29 Note 17 supra, 38-43.

30 United States v. Sioux Nation 448 US 371 (1980). Cf. United States v. Northern Paiute Nation 393 F 2d 786 (1968); 490 F 2d 954 (1974) (awarding compensation to tribe for taking of Aboriginal title to land and minerals in the fabled Comstock lode in Nevada, valued as of a date rather arbitrarily assigned as the date of taking, when the United States government began supporting the trespassing miners against the Indians).

31 Tee-Hit-Ton Indians v. United States 348 US 272 (1955).

32 United States v. Alcea Band of Tillamooks 329 US 40, 47 (1946) (footnote omitted). 
potential liability, for although the case before the Court involved land in Oregon, the then yet to be settled claims of the Alaskan natives, embracing perhaps several hundred million acres of land, were waiting in the wings.

It might seem surprising that such a fundamental issue was not decided for so long. Part of the explanation is that it was not until 1935 that Congress had enacted a generic statute clearing away the threshold defences, such as sovereign immunity, that the Court had regarded as preventing it from reaching the issue. In the past, in other words, the Court had usually been able to avoid scrutinising whether compensation was required for dispossessing Indians of their traditionally occupied lands, because it found judicial inquiry was precluded by one or another form of immunity, ${ }^{33}$ or because the tribes themselves had not attempted to challenge the adequacy of the compensation they had received for relinquishment of their traditional lands. ${ }^{34}$

This view of previous judicial reluctance to come to grips with the issue of compensation might be challenged as over-literal. A judicial decision to invoke sovereign immunity and refuse to review a decision by Congress on whether and how much compensation to provide was in effect a judicial decision licensing Congress to confiscate Indian lands. Recognising the government's sovereign immunity, in other words, was a decision to allow the government to refuse compensation with impunity.

Interestingly enough, this was not generally what happened. The historic federal policy had been, as the plurality opinion in Alcea Band observed, "not to coerce the surrender of lands without consent and without compensation." 35 Indeed, the plurality used that fact as an argument for recognising the legal obligation to compensate: "[s]omething more than sovereign grace prompted the obvious regard given [by the government] to original Indian title." ${ }^{36}$ The plurality felt, in other words, on firmer ground legally because it saw its decision merely as ratifying the status quo.

It was the dissent written by Justice Reed in Alcea Band, however, that eventually survived as the law. Within three years, Reed led a five person majority in Hynes v. Grimes Packing Co. which, in the course of striking down an executive branch order wholly excluding non-Indians from fishing in waters that were part of an Indian reservation, seemed to vest the government with broad power to take traditional Indian land

33 Id., 45-46.

34 See Nell Jessup Newton, "At the Whim of the Sovereign: Aboriginal Title Reconsidered" (1980) 31 Hastings $L J 1215,1228$. For a discussion of the few cases prior to Tee-Hit-Ton, note 31 supra, that had addressed the issue of compensation, 1226-1246.

35 Note 32 supra, 48.

36 Ibid. 
"without legal liabliity for compensation in any form..." later, the Court was in full retreat. In a later phase of Alcea Band, the question came before the Court whether the Band was entitled to interest (totalling some 14 million dollars) on the judgment of 3 million dollars it had been awarded by the lower court for the loss of its original title. Legally, the entitlement to interest rested on whether the compensation was based on the fifth amendment (the plurality's view in the lower court in Alcea Band), or on the special statute by which Congress authorised the suit to be brought (Justice Black's view). In a unanimous, cryptic, per curiam decision, the Court opted for Black's view, and thus the Indians' claim for interest on the judgment was rejected. ${ }^{38}$

Four years later, in 1955, following some changes in the Court's membership, the Tee-Hit-Ton case cemented the reversal into lasting form by a five to three decision. Significantly, both Tee-Hit-Ton and Hynes involved Indian claims in Alaska, a huge wilderness of potentially immense value that was also the last frontier, the only important area left where native claims had remained almost wholly unrecognised, unextinguished and uncompensated. The majority's concern about the effect on the Federal Treasury of holding Indian claims compensable was scarcely disguised. It referred auspiciously to a potential liability of 9 billion dollars for just some of the then pending claims (of which 8 billion would have been accrued interest) ${ }^{39}$ Ironically, at least in hindsight, the claims used to illustrate the potential liability were eventually resolved at a cost to the Treasury of 150 million dollars (without interest). ${ }^{40}$ Furthermore, in sharp contrast to the plurality in the first decision in Alcea Band, the majority in TeeHit-Ton emphatically rejected the idea that the rather consistent practice of paying compensation to extinguish Indian land claims supported the notion that there was a legal obligation to do so: "[t]his is not a case that is connected with any phase of [that traditional] policy ..."41

As noted earlier, the seeds of the uncertainty that provoked the Court's vacillation between 1946 and 1955 had been sown by John Marshall in Johnson v. McIntosh. While recognising the Indians' right to occupy their traditional lands, Marshall appeared to acknowledge the sovereign power of the government to extinguish that right "by

37337 US 86,103 (1949). The line-up of Justices was, to be sure, somewhat curious: Frankfurter and Vinson, who were in the plurality in Alcea Band, joined Reed's majority opinion here, while Rutledge, who joined Reed's dissent in Alcea Band, here dissented from Reed's majority opinion.

38 United States v. Alcea Band of Tillamooks 341 US 48, 49 (1951). See note 34 supra, 12311232.

39 Note 31 supra, 283, n. 17.

40 See note 34 supra, 1248-1249.

41 Note 31 supra, 273-274. 
purchase or by conquest." 42 Though the government had usually travelled the route of "purchase", and though the courts had generally insulated these transactions from their own scrutiny, the cases decided between 1946 and 1955 might be regarded as posing, in Marshall's phrasing, the question of when a "conquest" has occurred. For the plurality in Alcea Band, the idea of governmental conquest of what were by now its own citizens (citizenship having been generally granted to Indians in 1924) was so foreign, and the habit of purchase so engrained, that compensation deserved ratification as legal duty. For the majority in Tee-Hit-Ton, however, the concept of conquest remained applicable to the relationship between government and Indian. For these Justices, the government's payment of compensation in the past (and the majority seemed to deride the notion that these had been good faith transactions by referring rather scornfully to "blankets, food and trinkets") was provided "as a matter of grace", for ultimately the matter was settled by "the conquerors' will", that is by force or the threat of force. ${ }^{43}$ The Court did not elaborate on the reasons why this conquest, or this result, was "just", but its invocation of Johnson v. McIntosh was a deliberate effort to cloak itself in Marshall's analysis. ${ }^{44}$

Not surprisingly, the Tee-Hit-Ton majority's use of the conquest idea has been stridently criticised by commentators in Australia and Canada as well as in the United States. ${ }^{45}$ As Professor Newton put it,

[t]o say that the Alaska natives were subjugated by conquest stretches the imagination too far. The only sovereign act that can be said to have conquered [them] was the Tee-Hit-Ton opinion itself. ${ }^{46}$

Nevertheless, the result in Tee-Hit-Ton remains viable, having been referred to by the Court as settled law as recently as $1980 .{ }^{47}$ Remarkably, however, it seems not to have had a drastic effect on the government's policy or actual practice. For reasons elaborated more fully below, Tee-Hit-Ton's limitation on liability has remained more theoretical than real, for even where the national government arguably could have escaped any legal obligation to compensate Indians for confiscating their lands, it has chosen instead to pay. In fact, the only important remaining lands subject to unrecognised and unextinguished original Indian title at the time of the Tee-Hit-Ton decision were in Alaska. These claims were extinguished by legislation in 1971. Despite Tee-Hit-Ton's invitation not to pay, Congress awarded the Indians as

42 Note 13 supra, 587 (emphasis added). A later discussion by Marshall of the idea of conquest in relation to Indians is found in Worcester v. Georgia, note 14 supra, 542-558. See also note 9 supra. Whether Marshall actually ever acknowledged that conquest was a lawful means of extinguishing Indian title without compensation has been the subject of lively debate. See the authorities cited in note 34 supra, 1243, n. 175.

43 Note 31 supra, 281-282, 289-290.

44 Id., 279-280, 285.

45 See e.g. J. Hookey, "The Gove Rights Land Case: A Judicial Dispensation for the Taking of Aboriginal Lands in Australia?" (1972) 5 F L Rev 85,99,101; note 34 supra, 1241-1244.

46 Note 34 supra, 1244.

47 Sioux Nation, note 30 supra, 415, n. 17; cf. note 34 supra, 1284-1285. 
compensation 44 million acres of land, one billion dollars and assorted other benefits. $^{48}$

The general practice of paying compensation has not been perfect. For example, the courts have unblinkingly applied to certain kinds of Indian claims the rule that no interest is paid on certain kinds of recovery against the United States. ${ }^{49}$ But the fact remains that the United States government has for the most part committed to hold itself to a legal obligation, judicially enforceable, to deal fairly with Indian lands, and this includes Indian minerals. ${ }^{50}$ Whether this commitment is viewed as voluntary or legally mandated, it has for the most part governed the relationship between government and Indians concerning the disposition of land and land-based natural resources to which the Indians laid claim.

\section{Mineral Development Policy on Indian Reservations}

From the government's perspective, Indian mineral development has tended to be viewed as an instrument of Indian policy. Thus, its policy toward the development of Indian minerals has tended to follow the various twists and turns of national policy toward Indians in general. When the elimination of tribalism and the assimilation of Indians into the mainstream of American life was the explicit goal of national policy (and often pursued by coercive means), the Congress acted to encourage mineral development by distributing (allotting) minerals as well as land among individual Indians, and authorising these allottees to lease the minerals for development, with the approval of the Secretary of the Interior. ${ }^{51}$ At about the same time, Congress adopted numerous statutes authorising the leasing of tribal minerals for development. ${ }^{52}$ And occasionally Congress' enthusiasm for Indian mineral development as a path to assimilation led it to authorise the executive branch to lease minerals without tribal consent. ${ }^{53}$ This latter approach did not totally destroy the Indians' property interest in the minerals, for the revenues received were held for the benefit of the Indians, but it did remove an important aspect of the ownership interest - the right to say no to development.

48 See 43 U.S.C. $\S 1601 f f$. and A. Lazarus \& W.R. West, "The Alaska Native Claims Settlement Act: A Flawed Victory" (1976) 40 (1) Law \& Contemp Prob 132. For a discussion of this statute in relation to original Indian title, see note 34 supra, 1271-1277.

49 Cohen's Handbook, note 6 supra, 569-571; H. Friedman, "Interest on Indian Claims: Judicial Protection of the Fisc" (1970) 5 Val U L Rev 26.

50 See 25 U.S.C. $\S 70$; see generally Cohen's Handbook note 6 supra, 160-162,562-574. For a less favourable view of post-Tee-Hit-Ton practice, see note 34 supra, 1253-1283.

51 See 25 U.S.C. § 396, adopted in 1909; Cohen's Handbook, note 6 supra, 625.

52 Cohen's Handbook, note 6 supra. 533-535.

5325 U.S.C. $\S 399$, enacted in 1919. Cf. 25 U.S.C. $\$ 400$ (a), adopted in 1926, authorising the Secretary to lease certain Indian lands for mineral development. Though this act did not require tribal consent, it did provide that such leasing was to be "in accordance with existing law applicable to other lands in such reservation", which may incorporate a tribal consent requirement. 
However this approach was an aberration, even during the period when the national government was wholeheartedly pursuing its assimilationist policy. ${ }^{54}$ More often the government's policy was to exercise joint control of mineral development with the Indians themselves, each party having a veto over whether to lease at all and, within the statutory parameters, over the terms of the lease. When the general policy shifted back toward a revival of tribalism in the early 1930s, joint tribal-governmental control became firmly embedded in the legal topography, adopted as part of omnibus mineral leasing legislation enacted in 1938 in an attempt to bring uniformity to what had become a hodge-podge of ad hoc statutes governing Indian mineral development. ${ }^{55}$

This general approach has remained basically intact to the present. The degree to which either the tribes or the government has actually dominated the process has, however, varied over the years, and among the various tribes. At times the government has been very deferential to tribal wishes, while at other times it has been more aggressive in seeking to impose on the tribes its own conception of what is in their interests. The government's attitude has also varied depending upon the particular tribe involved and the historic relationship between each tribe and the local office of the governmental Bureau of Indian Affairs serving that tribe. These local offices have, by custom, usually enjoyed a large measure of independence in such matters.

Legally, however, the executive branch has remained subject to judicial scrutiny in its decisions, and been held to the standard of a fiduciary in its relationship with the tribes. Where it has, for example, been perceived as pre-empting a tribal opportunity for its own ends, it has been held liable for damages, even where those ends have related to the national defence. ${ }^{56}$ The standard does not require governmental perfection, of course, and does not insulate the tribes from all negative consequences, fiscal or otherwise, of their mineral development arrangements, but it does provide them some measure of protection and some judicial relief at least in circumstances where the government has behaved egregiously.

In the $1970 \mathrm{~s}$, as national policy shifted once again, this time in the direction of tribal self-determination, some tribes and the executive branch began to chafe within the confines of the limits created by the leasing statutes. Some tribes wanted to exercise entrepreneurial instincts by becoming more directly involved in mineral exploration and

54 E.g. the original Indian Mineral Leasing Act, adopted in 1891 (a few years after assimilation became official national policy), allowed the "council speaking for such Indians" to authorise leasing of certain Indian lands by the Secretary of the Interior. See also 25 U.S.C. $\S 398$, adopted in 1924 (same).

55 Cohen's Handbook, note 6 supra, 534. See also Crow Tribe of Indians v. Montana 650 F 2d 1104, 1111-1113 (9th Cir. 1981), cert. denied, 459 US 916 (1982).

56 See e.g. Navajo Tribe v. United States 364 F 2d 320 (Ct. Claims, 1966). 
development, and participating on a more forthright risk- and profitsharing basis. This not only suited the national government's policy of self-determination, but also indirectly satisfied those who still advocated assimilation, because it had a "let the Indians become capitalists" ring about it. (It should be noted, however, that this time the assimilation would be more voluntary than in earlier eras, because tribal participation in these more innovative ventures was not mandated nor, indeed, was development of tribal minerals in any form).

The result was adoption, in 1982, of the Indian Mineral Development Act, which supplemented, rather than replaced, the existing leasing program by authorising, under joint tribal/executive branch control, use of these more imaginative mineral development arrangements. ${ }^{57}$ One particularly interesting aspect of this legislation was its treatment of the national government's responsibility to safeguard Indian interests. On the one hand the statute seems to deny that the government is an insurer against any tribal loss stemming from a bad business decision, for it says that the United States "shall not be liable for losses sustained by a tribe or individual Indian" under any agreement approved by the Secretary in compliance with applicable law. ${ }^{58}$ On the other hand, the statute carefully preserves whatever trust responsibility the United States government had already assumed, for it says that nothing in the Act

shall absolve the United States from any responsibility to Indians, including those which derive from the trust relationship and any treaties, Executive orders, or agreement between the United States and any Indian tribe. ${ }^{59}$

It will remain for the courts to decipher this puzzle.

At about the same time that some Indian tribes were seeking a more entrepreneurial or managerial role in the mineral development process, some were concluding that past mineral development leases they had entered were unfavourable, owing especially to the dramatic increase in energy prices, stemming from the oil shocks of 1973 and 1979, that effectively and in some cases greatly devalued fixed price arrangements. The tribes generally were beginning more and more to flex their sovereign muscles, spurred on by the national government's policy of promoting sovereignty and tribal self-determination. ${ }^{60}$ Because a basic feature of sovereign authority is the power to tax, some tribes seized upon taxation of mineral operations on their reservations as a way at once to affirm their sovereignty, raise revenues, and mitigate the adverse consequences of the less provident mineral development arrangements they had earlier entered. The lessee mining companies were not willing to accede to this without a struggle, and the exercise of tribal taxing authority, while not entirely unknown in the past, had been sufficiently

5725 U.S.C. $\$ 2101-2109$.

5825 U.S.C. $\$ 2103(\mathrm{e})$.

59 Ibid.

60 See American Indian Policy Review Commission, Final Report Vol. I, 338-347 (1977). 
rare to leave the legal issue somewhat in doubt. The doubt was strengthened by the fact that the United States Supreme Court had begun, in the modern era, inventing some new "inherent" limitations on tribal sovereignty over non-Indians. ${ }^{61}$

But the doubts were removed in 1982 with the Supreme Court's decision in Merrion v. Jicarilla Apache Tribe, upholding the tribe's right to levy a severance tax on its own lessees. ${ }^{62}$ Though this decision was by a divided vote, and apparently painfully arrived at (the Court having taken the unusual step of having the case reargued in a new term of court), in 1985 the Court seemed to remove any lingering doubt about the matter by unanimously extending the decision to the most populous tribe, the Navajo. ${ }^{63}$ The Merrion decision had involved a tribal tax approved by the Secretary of the Interior whereas the Navajo tax neither needed nor received secretarial approval. The earlier decision had placed some emphasis on the protection to the lessees afforded by secretarial concurrence, but the Court in the Navajo case rather summarily rejected the distinction as inconsequential, and upheld the tax.

Obviously, tribal taxing authority, unless exercised judiciously or waived by explicit, advance agreement with mineral developers, has the potential to discourage new mineral development on Indian reservations. Though mineral developers run the risk of new tax burdens from local, state and federal governments everywhere they operate, they have less direct access to the political process on Indian reservations. Furthermore, tribal governments generally have a smaller tax base than most other governments, and are therefore more anxious to tax. It is too early to gauge the effect of these recent decisions. At this point it appears mineral developers, tribes and the national government are proceeding cautiously in dealing with this altered legal landscape.

Development of minerals on Indian reservations today can be described with some summary statistics on the leasing process - the 1982 Act authorising non-leasing arrangements being too new to have yet resulted in any actual mineral development. In 1982 (the latest year for which statistics are available) Indian lands contained 3,778 producing oil and gas leases (covering more than 1.2 million acres), 6 producing coal leases (covering more than 150,000 acres) and 33 producing leases for a variety of other minerals (covering 23,485 acres).$^{64}$ This mineral activity yielded more than 200 million dollars to the fifty-two separate Indian tribes with producing mineral leases in

61 See e.g. Oliphant v. Suquamish Tribe 435 US 191 (1978); Montana v. United States 450 US $544(1981)$.

62 Merrion v. Jicarilla Apache Tribe 455 US 130 (1982).

63 Kerr-McGee v. Navajo Nation 85 L Ed 2d 200 (1985).

64 See United States Department of the Interior, Minerals Management Service, "Mineral Revenues: The 1982 Report on Receipts from Federal and Indian Leases" (1983) tables 19 (58), 20 (39), 25 (62-63). 
1982, through rents, royalties and bonuses. ${ }^{65}$ Including non-producing leases in force on 31 December 1983, nearly 5 million acres of Indian land were under a total of 15,748 mineral leases. ${ }^{66}$

During the years 1920-1982, 1.151 billion barrels of oil, nearly 3.3 trillion cubic feet of gas and 256 million tons of coal have been produced from Indian lands. ${ }^{67}$ In the last four years for which information is available (1979-1982), Indian lands have produced 88 million barrels of oil (about $0.7 \%$ of total domestic production), 485 billion cubic feet of natural gas $(0.6 \%$ of total) and 100 million tons of coal (3\% of total) ${ }^{68}$

Though it is easy enough to manipulate or draw inconsistent inferences from statistics like these, a rather compelling case can be made that the tribal veto of mineral development has not thwarted mineral activity on Indian lands. The mining industry's continuing interest in dealing with Indians is also illustrated by the numerous articles appearing on the subject in industry practitioner publications. ${ }^{69}$

This is not to say that tribal decisions to lease minerals have always been free from controversy (apart from debate about the fairness, adequacy or enforcement of the lease terms, at which severe criticism has sometimes been levelled, though aimed much more at the federal government's discharge of its trusteeship responsibility than at tribal action).$^{70}$ In one well-publicised situation in the 1960s, the Hopi Tribe in Arizona, one of the more traditional tribes, was sorely divided over whether to participate with its neighbour, the Navajo Tribe, in leasing coal deposits in an area the tribes jointly controlled. The area, Black Mesa, had religious significance for many Hopis. Ultimately the tribe decided to participate, and litigation brought by tribal dissidents was dismissed because of the tribe's sovereign immunity. ${ }^{71}$

But this situation of outright opposition by a substantial segment of a tribe has been relatively rare. Even the Black Mesa situation was clouded by two facts: the particular area to be leased had special cultural significance, and the tribe itself did not totally control the decision because nearly all the area proposed to be leased was subject to leasing by the Navajo tribe even without Hopi consent. For the most part, in other words, the need for tribal consent to mineral development, and the need to negotiate the terms of particular arrangements with the tribes, has not meant a lock-up of tribal minerals. For some tribes mineral development has brought important economic benefits. Some tribes have also used their leverage to obtain more

65 Id., table $1 \mathrm{~A}(2)$, p. 39 .

66 Id., table $23(62-63)$.

67 Id., table $2(5)$.

68 Id., tables 2 (4-5), 25 (68).

69 See e.g. commentary cited in Cohen's Handbook, note 6 supra, 531, n. 23.

70 See Policy Commission Report, note 58 supra and authorities collected therein.

71 Lomayaktewa v. Hathaway 520 F 2d 1324 (9th Cir. 1975), cert. denied sub nom Susenkewa v. Kleppe 425 US 903 (1976). 
indirect benefits, such as the training and employment of tribal members. Tribal members who remain hostile to mineral development of any kind tend to be outvoted, for the lure of fiscal and other tangible rewards that tend to come with mineral development generally have proved too strong.

\section{BEYOND RACE: THE AMERICAN EXPERIENCE WITH SEPARATING MINERAL RIGHTS FROM SURFACE RIGHTS}

\section{Federal Reserved Minerals}

One other aspect of the American experience needs to be developed in order to set the stage for a comparison with the Australian one. As noted earlier, Indian control over minerals found on Indian reservations was generally established before the national government adopted a policy of reserving minerals in its conveyance of land. But once that policy took hold in the early part of this century, the government reserved minerals on most of the land it subsequently conveyed out of federal ownership. The result is that on some 66 million acres, the property estate is split - the national government owns the mineral rights under privately owned surface. ${ }^{72}$ (Actually, the surface owner also owns the subsurface except for the minerals, but it is convenient, if not entirely accurate, to refer to its property interest as 'surface' rights.) This situation is, as explained further below, close to the typical situation that prevails in Australia. Because Aboriginal land and mineral rights remain unresolved or the subject of continuing controversy, as is also explained further below, the private surface/government minerals situation provides an analogy that might be instructive. Therefore, it is useful briefly to examine the United States experience with such split estates.

The shift in government policy, to reserve minerals while disposing of the surface, came at a time when the government was beginning to convey land to support large livestock ranches in arid regions of the West. The fact that these so-called stock-raising homesteads did not embrace full fee title posed no significant problems for the first several decades of their existence. Even though the national government had reserved not only the minerals, but also the express "right to prospect for, mine, and remove the same" without payment (other than compensation for damage to "crops or other tangible improvements"), ${ }^{73}$ there was little mineral activity.

The first oil embargo in 1973 changed the picture dramatically, because it sent the government looking for alternative sources of energy, and its attention quickly came to rest on the huge deposits of

72 United States Department of the Interior, Bureau of Land Management, Public Land Statistics 1983 (1984) table $13(43-44)$.

73 Stockraising Homestead Act, 43 U.S.C. § 299. 
surface-mineable coal underlying many of these Western ranches, particularly in the Northern Great Plains of Wyoming, Montana and the Dakotas. Though the government possessed unquestioned authority to lease and develop these deposits without the ranchers' consent, it lacked the political will to do so. The ranchers organised themselves politically and aligned themselves with the growing power of environmentalists. In the end they obtained from Congress, as part of a statute imposing rather stiff environmental restrictions on coal surface mining, a provision requiring their consent to the leasing of coal underneath their property. ${ }^{74}$ This granting of a veto power allowed the ranchers to dictate the terms of coal development and to extract substantial financial concessions for themselves as the price of consent, even though they still technically lacked any ownership interest in the minerals. The "surface owner consent" provision, as it has come to be known, might be described as, in practical effect, the single most important transfer of property interests in federal lands in the last halfcentury.

In a direct confrontation between traditional rural and modern industrial interests, in other words, the rural interests won a nearly unqualified victory. In a sense, the result might be described as a victory for historic preservation - for allowing ranchers the opportunity to preserve their traditional way of life, a way of life celebrated in American folklore and exported to the world in film and television. If the remnants of this sub-culture were to be eliminated, congress decided, the developers and users of the coal deposits and their customers should pay, and if need be, pay dearly for it. That preservation was a key motivation was demonstrated by the statute's limitation of eligibility for the veto to those surface owners who had resided on the land for at least three years, or personally conducted farming or ranching operations upon the land, or received a significant portion of their income from such operations. ${ }^{75}$

Outside the context of coal, surface owners still lack a legal right to veto development of federally owned minerals. Yet in a practical sense they have been given, in various less formal ways, a substantial say in whether and how these reserved minerals would be developed. In several situations the national government has ruled out their development by simple fiat, responding in part to the political pressure of the surface owners. Sometimes this has been done by the Congress, and sometimes by the executive branch by means of so-called withdrawals. Sometimes the executive has exercised its discretionary authority over mineral leasing by refusing to grant applications to lease, because of the opposition of surface owners. ${ }^{76}$

74 Surface Mining Control and Reclamation Act, 30 U.S.C. $\S 1304$.

7530 U.S.C. $\S 1304(\mathrm{e})$.

76 See e.g. David Getches, "Managing the Public Lands: The Authority of the Executive to Withdraw Lands" (1982) 22 Natural Resources J 279. 
Finally, even where miners retain the legal authority to go onto this private surface and develop minerals, the customary industry practice in the past few decades has been to purchase the surface interest outright in order to avoid vexing litigation. Typically, in other words, the industry has chosen to pay much more than legally required in order to purchase, in effect, the surface owner's consent, even in situations where the surface owner legally has little or nothing to sell. ${ }^{77}$

\section{Privately Split Estates}

It must also be remembered that throughout most of the United States - specifically, in that nearly two-thirds of the nation that had passed into private ownership prior to the government's adoption of the policy of reserving minerals in conveyances - minerals are privately owned, usually by the surface owner. This has meant that most of the mining developments in the nation have taken place in circumstances where the surface owner had a full fee ownership and therefore a veto over mineral development. This tradition of surface owner authority over mineral development is thus a strong one.

In many situations the private owner of the complete fee has chosen to transfer the right to develop the minerals to a mining company - to split the estate between it and another private entity. It has in fact been a common practice for a century or more for fee owners throughout the Appalachian region of the Eastern United States, for example, to dispose of the rights to minerals under their land to coal industry representatives. Often these transactions were executed well before the technology to extract the coal by surface mining existed. In modern times, as those coal deposits have become more valuable and accessible by surface mining methods, the question has frequently arisen whether these old deeds conveying mineral rights should be construed to allow the extraction of minerals by methods that can utterly destroy the surface.

The answers of the various (mostly state) courts that have dealt with this issue have not been uniform, but the trend is unmistakable - the surface owner is winning more and more protection. Often, in fact, the courts have solved the dilemma by scrutinising the word "mineral" in the typical conveyance, and interpreting it to mean only minerals that can be extracted without destruction of the surface. This obviously limits the scope of the conveyance in a way that protects the surface owners. $^{78}$

77 See e.g. Ary \& Morgan, "Problems of Access to The Public Domain, State, and Fee Lands: From Shotgun to the Courthouse" (1969) 15 Rocky Mt Min L Inst 481, 494; Mall, "Federal Mineral Reservations" (1975) X Land \& Water L Rev 1, 44.

78 See e.g. John Lacy, "Conflicting Surface Interests: Shotgun Diplomacy Revisited" (1976) 22 Rocky Mt Min L Inst 731, 746-747; Sellers, "How Dominant is the Dominant Estate? Surface Damages Revisited" I3th Oil \& Gas Institute (1962) 397. 
The situation with respect to reserved minerals or split estates in the United States, then, is marked by a seemingly inexorable trend toward according the surface owner substantially more influence, frequently including a veto power, over development of mineral rights that legally belong to someone else. This reflects, of course, a fundamental shift in society's regard for the relative values of mineral extraction and surface uses, and a corresponding shift in answering the implicit question of who should more appropriately bear some of the costs and reap some of the rewards of mineral development - the extractors and users of the mineral or the person under whose land the minerals are found. The fact that the surface owner may never have been granted legal rights to the mineral, or may have acquired but then sold them, has not by itself been regarded as conclusive, though it can still remain important.

This shift in attitude in American society may be a useful benchmark in examining the Australian experience, to which I now turn.

\section{THE AUSTRALIAN EXPERIENCE - ABORIGINAL RIGHTS AND MINERAL DEVELOPMENT}

\section{Overview}

Aboriginal rights with respect to mineral development in Australia have had a far different evolution. The starting point seems at first blush nearly the polar opposite of its American counterpart. Because European settlement of Australia was not legally regarded as a conquest of the Aborigines but rather as equivalent (or at least akin) to settlement of an unoccupied or uncultivated land, the laws of the European settlers were deemed to apply from the moment of settlement. As a result, the Aborigines were deemed to have only such legal rights as the settlers were willing to give them.

Thus from the beginning of contract with Europeans, Aborigines in Australia were generally not regarded as comprising distinct communities with sovereign power over themselves or the territory they had traditionally inhabited. ${ }^{79}$ This meant, among other things, that dispossession of Aborigines by the European settlers was not accomplished or accompanied by any formal legal arrangements between the dispossessors and the dispossessed. For purposes of the present inquiry, it also has meant that whatever legal rights Aborigines have in land (and over the development of minerals found in that land) have been obtained through the political process, as a voluntary act by the settler government and not through the courts as a recognition of legal entitlement.

In a sense this view of Aboriginal rights - as existing only to the extent that the European-descendant-dominated government is willing to acknowledge they exist - is similar to the legal status of American

79 See e.g. Kenneth Maddock, Your Land Is Our Land (1983) 9-10. 
Indians. The American courts have over the years made quite clear that the United States Congress has the power to extinguish, as a matter of federal law, all aspects of Indian sovereignty and their special legal status. Congress could (and with respect to a few tribes, for a limited period of time, did) act to 'terminate' federal recognition of tribes and eliminate their sovereign control as tribes over their members and territory. ${ }^{80}$ Moreover, if the United States government had never previously 'recognised' or acknowledged Indian property rights in the territory they had traditionally occupied, it would not, at least according to decisions like Tee-Hit-Ton, have been liable to compensate the Indians for the property lost. (It is, in fact, probably not without significance that Tee-Hit-Ton itself was decided during the relatively brief flowering of the termination policy - the movement to rid the national government of most of its dealing with and responsibility for Indians.)

But on closer scrutiny, the comparison breaks down in several respects. First, and most important, in the American system what might be called the burden of legislative inertia has favoured the natives, while in Australia it has not. If the legislative branch does not act, the Indians in America retain their lands and their inherent sovereignty. Legislative inaction in Australia, on the other hand, means that Aboriginals are not accorded rights.

Second, and no doubt influenced by the custom of dealing with Indians as sovereigns with recognised legal rights, the American Congress has rarely acted to terminate federal recognition of tribes. Thus the power to terminate has remained largely theoretical. In Australia, on the other hand, it is recognition of Aboriginal rights that has remained, for most of the country's history, theoretical. Third, as was indicated earlier, the nearly uniform practice in the United States has been, legal obligations aside, to recognise Indian title, and to compensate Indians for property taken. That was not the case in Australia. For these reasons, the conceptual similarity in the scope of legislative authority over indigenous people in Australia and the United States is largely superficial, and certainly not an accurate indication of actual practice in the recognition of legal rights for these people.

The quite disparate treatment in law between American Indians and the Australian Aborigines was rooted in considerations of technology, security, social structure and international politics. As Professor Rowley has pointed out, ${ }^{81}$ American Indians were more organised for and skilled in warfare than Aborigines, and that made their dispossession much more difficult, and called for organised response by the Europeans. Yet the European technology was not nearly as advanced over indigenous technology in the 16th and 17th centuries in North

80 Cohen's Handbook, note 6 supra, 152-180, especially 170-175.

81 Charles Dunford Rowley, The Destruction of Aboriginal Society (1970) 11-26. 
America as it was in the 18th and 19th centuries in Australia, and the more equal bargaining power made sovereign-to-sovereign negotiations much more likely.

The Aborigines' lower population density, their comparative absence of agriculture and of settled villages, and their less obvious (if no less real, at least to modern investigators) social structure and system of land rights all helped make it easier for the European settlers to dispossess Aborigines and legally justify it as a process of settling an unclaimed land occasionally traversed by nomads, rather than of conquering indigenous inhabitants. As Rowley put it, the Aboriginal's "more subtle relationship with his country was either ignored or not understood." 82

Perhaps most important, both the invaders and the invaded were much more homogeneous in Australia than in the United States. The invaders in North America were politically disparate and competitive, and the Spanish, French, and British each continually jockeyed for favourable positions with the various tribes of indigenous peoples, whose assistance in armed conflict among European adversaries was often invaluable. From the Indians' standpoint, the various European nations could also be useful to play off against each other for advantage in dealing with a tribe's own Indian competitors. Not so in Australia, where the British settlers had no important rivals, and the Aborigines no obvious habits of internecine conflict. Moreover, compared to American Indians, the Aborigines had less to offer the European invaders in the way of labour or skills important to advance the settlement process, at least in the less arid coastal regions where nearly all settlement occurred.

Though the sharp difference in legal status the European invaders accorded to Australian Aborigines as opposed to American Indians has long been assumed and acted upon, it is curious, at least to this outside observer, that conclusive judicial resolution of the common law status of native land claims has been so delayed in both countries. In the United States, definitive resolution was not reached until Tee-Hit-Ton was decided in 1955. In Australia, the matter was addressed in a few 19 th century decisions, but none supplied a final judicial imprimatur on the practice of dispossession without compensation. ${ }^{83}$

This absence made it possible for an Aboriginal group in the late 1960s to argue, in opposition to mining in an area of land set aside as an Aboriginal reserve, that it had a common law legal right to the land and the minerals. Justice Blackburn for the Supreme Court of the Northern Territory rejected the claim in Milirrpum v. Nabalco Pty Ltd, popularly known as the Gove Rights case, holding that the doctrine of

82 Id., 14.

83 See e.g. John Hookey, "Settlement and Sovereignty" in Peter Hanks and Bryan Keon-Cohen (eds), Aborigines and the Law (1984) 1-10. See also Milirrpum v. Nabalco Pty Ltd (1971) 17 FLR 141, 242-262. 
communal native title "has no place in a settled colony except under express statutory conditons." 84

The matter was not finally laid to rest by this unappealed decision, however, and eight years later a High Court composed of four judges split evenly in a case that boldly, if apparently ineptly, sought to establish that Australia was conquered rather than settled by the British. ${ }^{85}$ The effect of the division was to affirm the lower court's judgment dismissing the claim without leave to amend, but the fact that two judges sided with the plaintiff is significant. One of the two judges was of the opinion that the traditional view of British settlement of Australia lacked unequivocal support in prior High Court or Privy Council decisions. ${ }^{86}$ The other thought an 1883 Privy Council decision that New South Wales was "practically unoccupied" when the British arrived "may be regarded either as having been made in ignorance or as a convenient falsehood to justify the taking of Aborigines' land." In any event, he pointed out, the High Court was no longer bound by Privy Council decisions. ${ }^{87}$ The division of the court in this modern case was hardly enough to lay the matter to rest.

It is perhaps tempting to make too much of this High Court decision. The two judges expressing views favourable to the plaintiff were not arguing that the British had occupied by conquest, but were only willing to allow the plaintiff to attempt to prove the point. The other two judges were rather vehemently opposed to the notion that Aborigines have some inherent sovereignty, though even they conceded that the correctness of the Gove Rights decision "would be an arguable question if properly raised." 88 On balance, then, the disputed outcome suggests rather plainly that the courts may not be entirely out of the picture as a forum able to provide some relief to Aboriginal rights claims. ${ }^{89}$

\section{The Role Of The Courts In Native Land Claims - A Digression}

Because the Australian courts have yet finally to disqualify themselves from the matter, it is worth pausing to see if there are any lessons for the Australian judiciary to be drawn from the American experience. It would seem that this experience sends some contradictory signals. The current law in the United States is that no compensation is owed for extinguishment of an 'unrecognised' right of occupancy. Thus Justice Blackburn was, in a strict sense, correct in relying on Tee-HitTon to find that the doctrine of communal native title as applied in the

84 Milirpum, note 83 supra, 143.

85 Coe v. Commonwealth of Australia (1979) 53 ALJR 403 affirming (1978) 52 ALJR 334 (Mason J.).

86 Id., 411 (per Jacobs J.).

87 Id., 412 (per Murphy J.).

88 Id., 408 (per Gibbs J.).

89 Another case now in the courts, Mabo v. Queensland offers a new opportunity to address these issues. See G. Nettheim, "Major Test Case" (1982) 4 Aboriginal Law Bulletin 1. 
United States did not support the Aborigines' claim in the Gove Rights case. $^{90}$

But the actual experience in the United States has been largely to the contrary; compensation has usually been paid to the Indians when they have been deprived of the land they have traditionally occupied. Significantly, most events in the three decades since Tee-Hit-Ton was decided have seen that long-standing policy confirmed rather than overturned. The practice of compensating the Indians has, in other words, been too much a part of the landscape to be dislodged merely by decisions of the United States Supreme Court.

Even that Court itself has, since Tee-Hit-Ton, sometimes displayed a greater sympathy toward Indian claims for compensation. This has been manifested, among other ways, in the ease with which the Court is willing to find congressional 'recognition' of Indian title to property, an event that, under the Tee-Hit-Ton approach, converts the mere privilege of occupancy into a compensable property right. The majority in TeeHit-Ton acknowledged that there was "no particular form" for this recognition, but did caution that somewhere, among the "variety of ways" it could be established, "there must be the definite intention by congressional action or authority to accord legal rights, not merely permissive occupation". ${ }^{91}$ But for a Court willing to look with some care and generous spirit, the very existence of a long-standing, generalised practice of recognising Indian sovereignty has made it very easy to find, in the myriad of federal statutes and orders dealing with Indians, a federal recognition of title. ${ }^{92}$

The crowning example of the government's policy of compensating Indians came, ironically enough, in Alaska, in settling the very claims that the majority in Tee-Hit-Ton seemed to view so nervously. The compensation paid for extinguishment of unrecognised native claims in the Alaska Native Claims Settlement Act of 1971 comprised, as noted earlier, large grants of land and cash. It was, according to the congressional findings prefacing the Act, a "fair and just settlement of all ... aboriginal land claims" in the state. ${ }^{93}$

To date, however, it remains the legal principle established in the Tee-Hit-Ton case, rather than the United States government's practice in dealing with Indian land rights, that has proved most relevant to the Australian courts. Though there are indications that the American policy of compensation may prove more useful as time goes by, at least in the legislative process, it was, significantly, Tee-Hit-Ton, and not the practice, that was used by Justice Blackburn in his Gove Rights decision. ${ }^{94}$

90 Milirrpum, note 82 supra, 217-218.

91 Note 31 supra, 278-279.

92 Note 34 supra, 1261-1264.

9343 U.S.C. $\S 1601$ (a).

94 Milirrpum, note 82 supra, 217-218, 262. 
The Gove Rights opinion has, however, been critised as misusing the Tee-Hit-Ton decision. ${ }^{95}$ Tee-Hit-Ton did not disturb the past decisions protecting original Indian title. Instead it held only that Indian title lacking formal 'recognition' by the government may be extinguished by the sovereign without compensation. Tee-Hit-Ton still requires, in other words, a sovereign act in order to extinguish the title, and that may or may not be found in the dispossession and displacement of particular groups of Indians. Thus the burden of legislative inertia remains on the Congress.

While this criticism is not without merit, it would not safeguard Aboriginal rights; specifically, it would not prevent the Australian government from now acting to extinguish Aboriginal title in the fashion approved in Tee-Hit-Ton. Furthermore, Tee-Hit-Ton implicitly adopted a very liberal standard for determining whether the sovereign had acted to extinguish Indian title. On the facts of that case, extinguishment was found where Congress had merely authorised harvesting of timber on land subject to Indian claims, "notwithstanding any claim of [Indian] possessory rights" to the lands in question, even though Congress disclaimed any intent of either "recognising or denying the validity of any claims of possessory rights" to the lands in question. ${ }^{96}$ Measured against this standard, it is possible that Aboriginal dispossession in Australia has already been accompanied by sovereign acts sufficient to satisfy Tee-Hit-Ton.

The Gove Rights approach, resting more on Tee-Hit-Ton's reasoning than on the general American policy that preceded and survived it, is not unusual considering the history against which it was set. A consistent practice, even one not expressly sanctioned by law (or adopted in response to its perceived dictates), can have an inertial force sufficient to thwart change. It can also have great gravitational force, attracting legal principle to it, and discouraging resolution of undecided legal questions in a way inconsistent with settled practice. The fact is that the United States has generally followed the practice of recognising compensable rights in land occupied by indigenous peoples, and Australia has not.

Established practice also tends to resist incremental change, at least where something as fundamental as land claims is at stake. Once a practice of compensating natives is undertaken, fairness among groups of natives tends to compel its continuation. It is more difficult, in other words, to adopt a practice that allows compensation in some circumstances and not in others, especially when, considered broadly, all indigenous peoples are in the same position vis-a-vis the invaders. This helps explain, for example, why Congress never seriously

95 R. Bartlett, "Aboriginal Land Claims at Common Law" (1983) 15 UWALR 293, 295-298.

96 Note 31 supra, 276. 
considered not compensating Alaska Natives after the Tee-Hit-Ton decision had licensed it to do so.

It was far easier for the courts in the United States eventually to adopt a legal principle contrary to long established practice than for Australian courts now to do the same, by acknowledging Aboriginal legal rights in the face of a rather consistent practice otherwise. Tee-HitTon, although contrary to prevailing practice, did not undo any transactions previously made. It merely established that the principled basis for these prior transactions had been moral, resting on qualities of fairness and generosity, rather than legal. In Australia, by contrast, judicial recognition of Aboriginal title could throw into doubt all prior transactions involving land subject to Aboriginal claims and cloud private land titles across the continent. This would be contrary to the considerable tenderness displayed by courts in both the United States and Australia toward the value of stability in property titles. ${ }^{97}$ Thus for Justice Blackburn in the Gove Rights case, the "important point" was not the historical accuracy of the conclusion that a colony was conquered or settled, but rather simply that the conclusion had been acted upon, and therefore was "not to be questioned upon a reconsideration of the historical facts."98

Nevertheless, the United States courts have occasionally leaped into the breach and made decisions that stimulated significant change in the status quo. In a related context, American courts in recent years have not hesitated to invalidate decades- or even centuries-old land transactions between Indians and others because they were executed without federal approval, as required by law. ${ }^{99}$ The effect of these decisions has been to cloud the property titles of often innocent purchasers of land in large areas of several eastern states. Though these decisions have created considerable controversy, judicial enforcement of the requirement of federal approval has been vindicated because some of these claims have been settled by negotiation and legislation restoring at least some land to Indians. Moreover, Congress has refused to invoke Tee-Hit-Ton by acting on requests that it legislatively extinguish the claims without compensation. ${ }^{100}$

In other well-known modern contexts, such as racial segregation and reapportionment, American courts have involved themselves directly into efforts to find solutions to important national problems, where other branches of government found themselves unable to act. ${ }^{101}$ Yet it still might be preferable to let the other more political branches take the

97 See e.g. United States v. Maine 420 US 515, $527-528$ (1980); Leo Sheep Co. v. United States 440 US 668, 687-688 (1979).

98 Milirrpum, note 82 supra, 202-203.

99 County of Oneida v. Oneida Indian Nation, note 15 supra; Cohen's Handbook, note 6 supra, 513-514; Clinton \& Hotopp, note 15 supra.

100 See Newton, note 34 supra, 1216-1217, n.9; 1277-1285; see also Monroe E. Price and Robert N. Clinton, Law and the American Indian (2nd ed.) (1983) 235-237, 642-644.

101 See e.g. J.H. Ely, Democracy and Distrust (1980) 65-66, 120-124. 
lead, for it would probably ensure a more general public support for resolving these land rights issues than might follow if the courts were to assume responsibility for going forward. Nevertheless, the American experience also suggests that there are situations where judicial deference to the other branches of government may lead either to no resolution, or to a resolution that, on balance, is arrived at more painfully than if the courts had boldly injected themselves into the debate. This may be particularly true, as John Hart Ely argues, where the claims of a racial minority, without substantial political influence, are at stake. ${ }^{102}$

But it would be a mistake to assume that the courts, in contrast to the more political branches of government, always resolutely stand on principle in the face of pressure to yield. The Tee-Hit-Ton decision is probably best explained by the majority's boggling at the magnitude of potential Indian claims for compensation in Alaska. ${ }^{103}$ The restraint the Court exercised there was not necessarily grounded in opposition to compensation, but opposition to the judiciary rather than the legislature making the decision to compensate, when that decision was seemingly so laden with important political and financial implications.

There are of course other principled grounds for judicial restraint on these questions. Judicial recognition that Aborigines have a legal right to land they have traditionally inhabited might carry with it certain stultifying rigidities. In determining adequacy of compensation for lost Aboriginal lands, for example, the judicial tendency would probably be to borrow from the elaborate doctrines and extensive case law that mark the determination of just compensation in the exercise of eminent domain. Yet one could say that this would not necessarily lead to equitable results, both because it might 'overcompensate' Aborigines for certain features that were not important to them but exceedingly important to Europeans (minerals, for example), yet might 'undercompensate' Aborigines for losses not traditionally accounted for in conventional eminent domain proceedings (for example, loss of sacred sites and, more generally, destruction of distinctive cultural attributes).

One could say, then, that the political process might function better than the judicial process in accounting for these losses. Perhaps this is what Justice Robert Jackson of the United States Supreme Court had in mind when he opposed making compensation for loss of original Indian title "a rigid constitutional principle" and hinted at the difficulty for the judiciary if it "tried to put a value on" these rights. ${ }^{104}$ Still, though the point does not lack force, it should not be assigned too

102 Id., 135-179.

103 See Newton, note 34 supra, 1248-1249.

104 Northwestern Bands of Shoshone Indians v. United States 324 US 335, 355 (1945), quoted with approval by Justice Reed in Tee-Hit-Ton, note 31 supra, 290-291. But see Newton, note 34 supra, 1250-1251. 
much value. The courts in the United States have not hesitated to assume the responsibility given them by the Congress for deciding, through conventional judicial processes, whether the government's past dealings with particular groups of Indians were, among other things, "fair and honorable". ${ }^{105}$ Whatever strains this rather unusual responsibility might have put on the judicial function, they have not led to any fervent cries for relief from any of those directly involved.

In the end the courts are not without influence, and if they utterly abandoned the field, the course of political response to land claims would probably be much more uncertain. While Felix Cohen does properly celebrate the United States government's willingness to hold itself generally to a judicially enforceable standard of fair and honourable dealings with Indians, his failure to anticipate Tee-Hit-Ton does cast a shadow on his praise for United States policy. ${ }^{106}$ That decision in effect carved out (or allowed Congress to carve out) an exception to that standard where 'unrecognised' or 'original' title is concerned. It has meant, in turn, that the fairness of any post Tee-HitTon resolution of a claim has become more difficult to judge.

The case may be put this way. Tee-Hit-Ton says rather clearly that Congress was under no legal obligation to compensate the Alaska Indians for loss of their traditional lands. Sixteen years later, Congress did compensate them, in both land and cash, for extinguishing all their claims. But was the settlement fair? Is it appropriate to assume that in this situation Congress might behave as would a negotiator in a private adversarial dispute, and adjust the value of the offer of settlement by an assessment of the difficulties, judicial or otherwise, that the adversary could cause it?

This question, like so many in this complicated area, cannot be answered conclusively. For this reason, it is difficult to draw clear lessons for the Australian judiciary from the long and rather varied American experience. In any event, the spotlight has shifted in recent years in Australia to the legislative process as an arena for resolving Aboriginal land claims.

\section{Legislative Resolution of Aboriginal Land Claims}

Despite the negative (if still less than definitive) results reached in judicial proceedings (or perhaps because of these results), Aboriginal land rights advocates have been considerably more successful in pursuing claims through the legislative process. The Gove Rights decision in fact proved to be something of a catalyst that stimulated, first, a major study of the land rights question in the Northern Territory by Justice Woodward, and then political action, resulting eventually in

105 See 25 U.S.C. $\$ 70(a)$.

106 Cohen, note 17 supra, 56-57. 
enactment of landmark land rights legislation in the Northern Territory by the Commonwealth Parliament. ${ }^{107}$

Though this legislation applied only in the Northern Territory, and was thus well within the constitutional power of the Commonwealth over territorial matters, it did mark a rather novel departure for, and new resolve by, the federal government in dealing with Aboriginal matters. The resolve was particularly significant because a constitutional amendment in 1967 had eliminated the Commonwealth's prior constitutional inability to legislate with regard to Aboriginal rights in any state. The 1967 amendment had not disabled the states from continuing to deal with Aboriginal issues, but its passage by an overwhelming margin had given the national government much more leverage over Aboriginal affairs. ${ }^{108}$

Initially quite cautious, the federal government has gradually become more aggressive about wielding its new authority to encourage the state governments to address Aboriginal land claims. It has been aided in this more assertive course by recent decisions of the High Court. ${ }^{109}$ These decisions have taken a quite broad and benevolent view of the Commonwealth's constitutional power over Aboriginal affairs. They have also given the Commonwealth considerably expanded freedom of action to intervene in traditionally state affairs in order to legislate to advance the interests of Australia in the international arena. Because land rights for indigenous peoples have become a focus of international organisations in recent years, ${ }^{110}$ this second expansion of Commonwealth constitutional power might also prove important.

Assuming that the courts do not adopt a common law principle (or apply any emergent international law doctrine) that recognises Aboriginal land rights, the matter will continue to be pursued at political levels. The discussion that follows will, for simplicity's sake, assume that the political decision has been or will be made to grant Aborigines recognised rights in specific tracts of land. What remains for further analysis is the question of mineral rights on those lands. Though some of the discussion focuses on Western Australia, it does not, given the constitutional discussion above, depend upon whether legislation comes from the states or the Commonwealth - reference is made simply to government or the Crown.

107 See e.g. Bryan Keon-Cohen and Bradford Morse, "Indigenous Land Rights in Australia and Canada" in Aborigines and the Law, note 83 supra, 76-102; Judith Wright, "Landscape and Dreaming" in The Daedalus Symposium, note 1 supra, 53-55; R.P. Maxwell, "Mining and Its Interaction with Commonwealth and State Laws Relating to Environmental and Aboriginal Issues" AMPLJ 4(1) (1982) 76-78, 81-85.

108 P. Hanks, "Aborigines and Government: The Developing Framework" in Aborigines and the Law, note 83 supra, 19, 23-24.

109 See e.g. Commonwealth v. Tasmania (1983) 46 ALR 625, 737, 817-818 (The Franklin Dam Case); Koowarta v. Bjelke-Peterson (1982) 56 ALJR 625, 631; P. Hanks, note 108 supra, 2437.

110 G. Nettheim, "The Relevance of International Law" in Aborigines and the Law, note 83 supra, 50-73. 
In the context of the particular issue on which this paper focuses Aboriginal control over mineral development - the government would seem to be free to adopt, within the parameters set by political feasibility, any approach it wants to the question. On the the one hand it could simply vest Aborigines with fee title to the minerals and give them absolute, unreviewable discretion to control whether and how the minerals are to be developed. It might even, at the extreme, vest Aboriginal groups with sovereign authority to regulate and tax mineral development, though this would, in theory at least, not add a great deal to the powers they would already enjoy, as owners of the resource, in fixing the terms of its development. On the other hand, the government could deny Aborigines any rights at all in minerals, leaving the decision whether and how to develop, and the disposition of any financial benefits that flowed from it, exclusively to the government itself.

If the United States' approach were followed, something very much like the former would be selected. Aborigines would be given nearplenary control over the minerals under the land reserved to them, including a veto power over development and substantial negotiating rights over its terms. The only important limitations in the United States are that, first, the government's executive branch retains the right, under its trusteeship responsibility, to veto mineral development to which Indians assent; and second, as discussed earlier, the United States Congress has by statute established some rather broad parameters limiting tribal mineral arrangements.

In the arrangements adopted to date in Australia, the power of Aborigines to control whether and under what conditions mining may take place on Aboriginal reserves varies somewhat from jurisdiction to jurisdiction. In the Northern Territory, earlier in this century, mining in Aboriginal reserves was flatly prohibited. Nevertheless, just as occurred in the United States a few decades earlier, when valuable minerals were suspected to exist in the reserves, miners were able to gain access by exercising political pressure to declassify the reserves. Unlike the situation that usually obtained in the United States, however, the Aborigines were not compensated either for loss of the reserved land or for any minerals extracted. ${ }^{11}$

Today in the Northern Territory, the law gives the Aborigines a veto over mineral development and considerable, if not quite plenary, power to negotiate terms and conditions of entry. ${ }^{112}$ There is, however, a provision allowing the government to override Aboriginal objection to mining when it is in the "national interest", and the Territorial government has objected to any arrangement that has given the Aborigines any sort of payment based on the value of the mineral extracted, arguing that this invades the Crown's ownership interest in

111 Jon C. Altman, Aborigines and Mining Royalties in the Northern Territory (1983) 3-4.

112 Seven Years On, note 5 supra, 61-63, 77-93. 
the mineral. ${ }^{113}$ In parts of South Australia, too, it appears that mineral development may take place over Aboriginal objections in some carefully defined circumstances, but Aboriginal interests are somewhat protected. ${ }^{114}$ In Western Australia, the government currently has broad authority to permit mining on Aboriginal reserves over Aboriginal objection. ${ }^{115}$ In most of these jurisdictions, however, the issue remains highly controversial. Moreover, the possibility that the Commonwealth will adopt a single, uniform approach, pre-empting regional solutions, is a real one. ${ }^{116}$ The lack of a consensus on the question suggests that some useful guidance might be obtained by looking at how mining is treated when Aboriginal interests are not involved.

\section{THE PRIVATE LANDOWNER'S RIGHT TO CONTROL MINERAL DEVELOPMENT IN AUSTRALIA}

Giving the Aborigines, like the Indians, a veto power and substantial control over mineral development is not substantially different from the practice that prevails on most private land in the United States (where the surface owner also owns the minerals and exercises great authority over their development). In Australia, however, this approach seems susceptible to the charge that it is vesting Aborigines with some rights over mineral development that most private landowners lack. That is, throughout most of Australia, the Crown has, in transferring land to private ownership, reserved and retained the mineral rights. Though this policy was not always followed in the 19th century, it has been in the 20th, with the result that the minerals under most private land in Australia belong to the state governments. ${ }^{117}$

In Western Australia, for example, gold and silver under all land belong to the Crown. Minerals under land transferred out of state ownership between 1887 and 1899 were, in the discretion of the Governor, reserved to the State. After 1899, the policy of state reservation of all minerals was made uniform and automatic. Detailed information concerning the status of mineral rights is hard to come by,

113 See H.N. Morgan, "The Mining Industry and Aborigines" in R.M. Berndt (ed.), Aboriginal Sites, Rights and Resource Development (1982) 192-193.

114 See Maxwell, note 107 supra, 83-84.

115 See Seaman Report, note 4 supra, 178; Graham McDonald, "Aboriginal Land Rights in Western Australia Relating to Mining and Petroleum Exploration and Development" (1979) 2 AMPLJ 282. For a detailed comparison of various approaches, see Michael Barker, "Aborigines, Natural Resources and the Law" (1983) 15 UWALR 245, 257-292.

116 See "Commonwealth Preferred National Land Rights Model" (mimeo, released 20 Feb. 1985); Douglas G. Williamson, "Aboriginal Land Rights, The Preferred National Land Rights Model" (paper presented to the Australian Mining and Petroleum Law Association, Ninth Annual Conference, Sydney, June 12-15, 1985); Garth Nettheim, "Holding Ground" (mimeo, June 1985).

117 See e.g. Australian Mining and Petroleum Laws, note 1 supra, 11-25. 
but there is general agreement that the privately owned mineral estate in Western Australia is relatively small. ${ }^{118}$

It can of course be argued with considerable force that the private land analogy is simply inapplicable to the Aboriginal rights question. Recognising Aboriginal land rights is in some measure an act of restitution, of restoring to the descendants of the Aboriginal peoples originally dispossessed or denied legal rights as nearly as practicable the same amount of dominion and control over the land that their ancestors enjoyed. Given that objective, the amount of rights the government has been willing to grant to ordinary citizens is arguably irrelevant. As one observer has noted,

Aborigines can argue with great justification that they have usually occupied a special position in Australia. ${ }^{119}$

Though this argument is not without force, it has not, to date at least, proved conclusive. For one thing, Aboriginal culture prior to European contact did not involve mineral development; in fact,

[o]f all the European activities mining must have appeared to be the least rational, the most incomprehensible [to Aborigines]. ${ }^{120}$

Minerals made valuable because of imported industrial technology should not, it might be argued, be controlled by traditional Aboriginal notions of dominion and control. Also, to differentiate between Aborigines and others on this question raises the issue of differential treatment based on race. This is always a sensitive subject, but is at least partially answered by the fact that the original dispossession of Aborigines by Europeans could also be viewed as differential treatment based on race, so that contemporary recognition of Aboriginal land rights is merely remedial, and acceptable on bases customarily used to justify so-called 'affirmative action' measures.

It now seems clear, given the recent decision of the High Court in Gerhardy v. Brown, ${ }^{121}$ that there is no legal objection to singling out Aborigines for benevolent treatment different from that accorded other parts of the population. The same result has been reached numerous times by the courts in the United States, sometimes on the theory that the classification of Indians is political rather than racial, and sometimes because it is a benevolent and therefore justifiable racial distinction to make. ${ }^{122}$

It might also be argued that recognising or conveying mineral rights to Aborigines is not differential treatment at all. The Crown has routinely recognised or conveyed rights to minerals to private nonAborigines. These conveyances have been in the form of mineral leases or tenements. While it is true the Crown has not, since the turn of the

118 Mining Law in Western Australia, note 1 supra, 38.

119 Maddock, note 78 supra, 164.

120 Henry Reynolds, The Other Side of the Frontier (1982) 153.

121 (1985) 59 ALJR 311.

122 See e.g. Morton v. Mancari 417 US 535 (1974); Livingston v. Ewing 601 F 2d 1110 (10th Cir. 1979); United States v. Decker 600 F 2d 733 (9th Cir. 1979). 
century, vested mineral rights together with surface rights in the same entity, but rather chosen to vest them in separate entities, this does not make it discriminatory to choose to vest them in a single entity where Aboriginal claims are concerned.

But to the extent it is true that Aborigines would be granted a veto over mineral development in circumstances in which most other private landowners lack one, the argument clearly carries some political weight. Therefore it is worth considering the extent to which non-Aboriginal surface owners have a right to veto mineral development in both contexts in which it occurs: when the mineral rights are owned by the surface owner, and when they are owned by the Crown.

\section{Privately Owned Minerals}

Looking first at those relatively few private landowners in Australia who also enjoy ownership of the minerals, most enjoy the common law rights of full dominion and control over the minerals. These include the right to veto development and extract whatever payment they can for these rights, subject to resumption (condemnation) by the state for public purposes upon payment of compensation, and subject also to regulation to protect the general welfare. ${ }^{123}$ Some Australian states have, however, partially reversed the common law principle by legislation, and allowed mineral developers in some circumstances to force the private owners of the minerals to allow their development. For example, the Victorian Mines Act 1958 specifies that where a geologist concludes there is a "reasonable probability" that privately owned land contains minerals in "paying quantities", the land and its minerals become the property of the Crown, and subject to mineral development under the laws applicable to Crown minerals, unless the owner undertakes mining within six months thereafter. If the Crown does take title, the former owner of the minerals would receive, as compensation, $90 \%$ of the rental and royalty payable to the Crown. Western Australia had a similar provision until relatively recently, but it was apparently never invoked. ${ }^{124}$

This statutory system, described by one judge in Victoria as a "quite radical ... interference with the common law rights of the landowner", ${ }^{125}$ goes well beyond anything with which I am familiar in the United States. It represents a seemingly rather extreme solution to the balancing of a vested private interest in property and the usefulness of mineral development to a society. Nevertheless, it can be seen as functioning much like the power of resumption - likely valuable deposits of minerals are, by this approach, simply resumed or

123 Australian Mining and Petroleum Laws, note 1 supra, 175-183.

124 Id. 175-177.

125 Wade v. New South Wales Rutile Mining Co. Pty Ltd(1969) 121 CLR 171, 195 (per Windeyer J.). 
condemned by the Crown with the compensation being set at a fixed royalty and rental rate.

While this statutory scheme does not give the private mineral owner a veto against development, neither does that owner have a veto against ordinary resumption by the Crown of his mineral interest. Neither, in general, do American Indians have the right to veto condemnation of their property interests for a public purpose by the government. ${ }^{126}$ In the final analysis, however, the fact that this statutory system has apparently been little if ever used, ${ }^{127}$ suggests it has probably been unworkable both politically and technically.

Despite this unusual statutory limitation on the property right of the private mineral owner, it seems that if Aborigines were given a veto power over mineral development in lands reserved for them, it would not, on balance be a dramatic departure from the situation that prevails in both the United States and Australia with respect to privately owned mineral rights.

\section{Minerals Reserved to the Crown}

In the much more common Australian situation, where minerals in private land have been reserved by the government, the legal rights of the private surface owner are somewhat harder to decipher. In Western Australia, for example, surface owners have the right to veto mining of minerals on their land only under what initially seems like a narrow range of circumstances. First, the veto is only effective against mineral activity that occurs within thirty metres of the lowest part of the surface. Second, it is only effective where the land falls into certain specified categories, including small-sized parcels, parcels with "substantial" improvements, cemeteries, reservoirs, gardens, vineyards, and "land under cultivation". Because nearly all mining, even of deep deposits, requires some activity within thirty metres of the surface, the first limitation has not proved significant. Also, the category of "land under cultivation" was greatly broadened in a 1970 amendment to include land, whether cleared or uncleared, that is used for grazing of stock, as well as cropped and pastured land. The vast bulk of private land in the State is used for grazing; thus, the net effect has been effectively to require the surface owner to consent to mining of Crown minerals under practically all privately owned land in Western Australia. ${ }^{128}$

This legislative grant of a veto power is not, however, quite the same thing as vesting the surface owner with an ownership interest in the minerals. For one thing, whether mineral development actually occurs depends also upon the government's willingness to grant approval. Second, the surface owner who consents to mining is, under the statute,

126 Note 10 supra and accompanying text.

127 See Mining Law in Western Australia, note 1 supra, 56-57.

128 Id., 23, 54-55. 
entitled to compensation for "all loss and damage suffered or likely to be suffered" as a result of mineral activity. But this section of the Mining Act also provides that compensation is not payable "in respect of the value of any mineral"; that is, royalties or other measures of compensation based on value are not lawful. ${ }^{129}$ But the miner still needs the surface owner's consent, and the statute does not forbid selling that consent for a royalty interest. As a matter of practice, then, the need for the surface owner's consent has, in the words of the leading analyst of Western Australia's Mining Act, given "the farmer whether owner or occupier a lever to negotiate royalties and share of profits." 130

The practical effect of the surface owner consent provision, then, has been to transfer what amounts to an ownership interest in the minerals to the surface owner. The surface owners have, moreover, often negotiated substantial rewards as the price of consent, or simply withheld consent altogether, thwarting mineral activity on much private land in Western Australia. In one compilation furnished by a mining industry association, 287 landowners were approached about consent, and nearly one-third refused, and more than one-third are still in negotiations. No information was supplied on the terms of the consent provided by the fewer than one-third that consented. ${ }^{131}$

This consent requirement has proved highly controversial. The mining industry, supported by the current Labor government in Western Australia, has attempted to limit the surface owner, veto by legislation in recent years. The attempt has so far been thwarted by the Upper House in the Western Australia legislature.

\section{SOME CONCLUDING THOUGHTS}

In the context of comparing the rights of non-Aboriginal land owners with Aborigines, the lessons seem reasonably clear. Most nonAboriginals who have interests in property, but not mineral rights, have been given effective control over mineral development on their property in Western Australia. This control now includes, as a practical matter, the right to extract financial concessions measured by the value of the minerals produced. This collection of rights closely approaches what the law typically regards as an ownership interest in the minerals. If this approach is used as the model, then granting Aborigines a veto power would, as the recent Seaman report recognises, be placing Aborigines in

129 Id., 54-55.

130 Michael W. Hunt, "The Legislation Relating to Aboriginal Land Rights in Western Australia with Particular Reference to Mining and Petroleum Exploration and Exploitation" (1982) 4 (1) Mining and Petroleum Law Journal 201, 207. See also the Report of the Inquiry into Aspects of the Mining Act (1983) to the Minister for Minerals and Energy. State of Western Australia (Michael W. Hunt, Chair of the Inquiry Committee, 1983) 89-90.

131 Report of the Inquiry, note 130 supra, 242-243. 
a legal position not effectively different from that enjoyed by nonAborigines. ${ }^{132}$

This is not to say the analogy is perfect, or the experience readily transferable. Yet the differences that do exist cut both ways. Cutting in favour of granting Aborigines such rights is the fact that the surface owner consent provision of current West Australian law is based on categories of land use that are deemed of special value by society. In the case of cemeteries, for example, that value is respect for the dead. Agriculture and stock-raising are accorded special value in the various land cultivation categories. Each category represents, in other words, a legislative decision, after implicitly balancing the trade-offs involved, that the surface owner should have authority, along with the miner and the government, to determine whether mineral development takes place.

This approach would appear to comport comfortably with the traditional Aboriginal relationship with land. ${ }^{133}$ Existing law in Western Australia already authorises special protection for sacred and other sites of cultural significance, though the degree of protection is subject to the informed discretion of the executive, and is neither absolute nor subject to control by the Aborigines themselves. To grant a veto power over at least that land bearing special significance for Aboriginal communities is consistent with the spirit of the current legislative allocation of veto power in the private non-Aboriginal context.

On the other hand, the amount of private land in Western Australia is a comparatively small proportion (about $8 \%$ ) of the total area of the State. ${ }^{134}$ Although lands in Aboriginal reserves in Western Australia now comprise about $7.5 \%$ of the State's land area, ${ }^{135}$ lands that Aborigines are likely to claim could well embrace much larger areas. In the Northern Territory, for example, $45 \%$ of the land is held or has been subject to claim by Aborigines. This in effect may raise the stakes well beyond the level at issue in the context of ordinary private land, making the analogy to private lands harder to draw.

Nevertheless, it seems reasonably clear that, in Western Australia at least, land subject to Aboriginal claims is presently less the focus of mineral industry interest than land controlled by non-Aboriginal farmers and pastoralists. The latter lands often lie in geologically favourable zones, and sometimes near sites of existing mineral production. Also, transportation costs are lower and an infrastructure to support mineral production is already in place or much more accessible than is the case with most Aboriginal controlled land. ${ }^{36}$ This fact could

132 Seaman Report, note 4 supra, 165.

133 See e.g. Judith Wright, note 107 supra, 31; Ronald M. Berndt, "Traditional Concepts of Aboriginal Land" in Aboriginal Sites, Rights and Resource Development, note 113 supra, 2; Woodward J., Second Report of the Aboriginal Land Rights Commission (1974) 104.

134 Seaman Report, note 4 supra, 181.

135 Ibid.

136 Report of the Inquiry, note 130 supra, 232-234, 240. 
lead one to suggest that the industry's greater interest, in Western Australia at least, is to limit the non-Aboriginal surface owner veto. The industry's strident opposition to the Aboriginal veto may simply be the camel's nose in the tent of greater access - with the real prize being repeal of the non-Aboriginal surface owner veto. In other parts of Australia, however, it may be that the Aboriginal veto will have a more chilling effect on areas of industry interest than in Western Australia. ${ }^{137}$ So far, however, the results in Western Australia have the farmers and pastoralists up one-nil against the miners, and the miners one-nil against the Aborigines, as the Upper House has refused either to modify the farmer/pastoralist veto, or to countenance any serious control by Aborigines over mining activity on Aboriginal reserves.

Reflecting for a moment on the American situation, it may well be the case that Indians control a smaller percentage of the mineral wealth in the United States than the Aborigines could potentially control in Australia, but such comparisons are quite difficult to make. Though American Indians control mineral development on less than $2 \%$ of the nation's land area, most of the larger Indian reservations are in Oklahoma and other Western states that have historically yielded a major share of the nation's mineral wealth. Moreover, indigenous peoples now control well over $10 \%$ of Alaska, touted by some as the next major mineral frontier in the world and already the site of some world class mineral discoveries. The United States General Accounting Office estimated in 1976 that Indians controlled about 3\% of the total United States reserves in oil and gas, and between 7 and 13\% of the total identified United States coal reserves. ${ }^{138}$ The comparison demands, then, that some risky assumptions be made about likely mineral discoveries, and about the amount and location of land that will prove politically feasible for Aboriginal groups to obtain.

Thus while Aboriginal land in Australia may well prove somewhat more valuable for minerals than American Indian land, the difference may not be dramatic. Indeed, the possibility that Aboriginal lands may prove less valuable than American Indian lands seems real enough not to be dismissed out of hand. There will, moreover, probably be an inverse relationship between the amount of land Aborigines obtain and the degree of control they will be allowed to exercise over mineral development - the greater the control, the smaller the land area the government is likely to grant. Given the uncertainties rife in such a comparison, it probably should not be a significant factor in drawing conclusions from the American situation.

137 See e.g. R.M. Berndt, "Mining Ventures: Alliances and Oppositions" in Aboriginal Sites, Rights and Resource Development, note 113 supra, 238.

138 U.S. Comptroller General, General Accounting Office, Report to the Senate Committee on Interior and Insular Affairs on Indian Natural Resources, Part II, "Coal, Oil \& Gas" (1976). 
There is yet another pitfall to looking to the situation of the American Indian vis-a-vis mineral development for guidance. As noted earlier, one aspect of the inherent sovereignty American Indian tribes have long been recognised as possessing is the right to tax non-Indians, including mineral developers, who engage in commerce on the reservations. ${ }^{139}$ Tribal sovereignty also embraces the right to exclude non-members from the reservation under certain circumstances, ${ }^{140}$ and the right to shield many tribal actions from judicial review by invoking the principle of sovereign immunity. ${ }^{141}$ Furthermore, in many situations non-Indian developers may be unable to find a state or federal court with jurisdiction to enforce, or award damages for breach of, mineral agreements with Indian tribes. Commercial contracts between Indian tribes and non-Indians are ordinarily not construed to give rise to questions of federal law cognisable in a federal court. ${ }^{142}$ State courts usually have no jurisdiction over Indian contracts, ${ }^{143}$ and federal jurisdiction based on diversity of citizenship of the parties ordinarily does not obtain. ${ }^{144}$ Tribal courts may be open to such claims, but success there may be far from assured. ${ }^{145}$

The upshot is that in many, perhaps most situations, non-Indian mineral developers in the United States lack both a clear remedy in the event of tribal breach, and substantial protection against the exercise of tribal taxing and regulatory power. Interestingly, though the increase in business risk this entails probably dampens the mining industry's interest in developing Indian minerals, it has plainly not eliminated it. In Australia, by contrast, none of the solutions offered by any of the disputants contemplates an Aboriginal sovereignty or immunity akin to that enjoyed by American Indian tribes.

Returning to comparison between Aboriginal and private lands in Australia regarding control of mineral development, the private land analogy can also be challenged on economic grounds. Giving agriculturalists a veto power over mineral development on their lands can be justified as a weighing of the economic trade-offs between agricultural and mineral contributions to economic growth. Much Aboriginal land, on the other hand, may not be put to uses that make significant contribution to the economy. If cold calculations aimed at

139 See note 7 supra and accompanying text.

140 See e.g. Merrion v. Jicarilla Apache Tribe, note 7 supra; Hardin v. White Mountain Apache Tribe (9th Cir. 22 May, 1985).

141 Cohen's Handbook, note 6 supra, 324-328; Santa Clara Pueblo v. Martinez 436 US 49 (1978).

142 Cohen's Handbook, note 6 supra, 311-313; Gila River Indian Community v. Henningson, Durham \& Richardson 626 F 2d 708 (9th Cir. 1980).

143 Cohen's Handbook, note 6 supra, 349-352.

144 Id., 317.

145 Cf. Dry Creek Lodge v. Arapahoe and Shoshone Tribes 623 F 2d 682 (10th Cir. 1980), cert. denied 449 US 1118 (1981); National Farmers Union Insurance Cos v. Crow Tribe, 85 L Ed 2d 818 (1985). 
maximising wealth are followed, mineral development may not be made subject to Aboriginal veto.

Such economic analysis has its limitations, of course, and most would concede it should only inform, rather than control, resolution of such a difficult issue. If one followed the dictates of readily measurable economic indicators, for example, one would probably conclude that in most situations agriculturalists should not have a veto over mining either, because agriculture currently contributes substantially less to the economy than mining. Still, while the relatively large economic importance of mining in Australia, and particularly Western Australia, cannot be ignored in the political process, neither does it demand slavish obedience to the call for removal of all barriers to mining that some would imply from it.

Indeed, considerations of economic efficiency and wealth maximisation are probably not powerful enough to justify ignoring other factors based on equity. Giving Aborigines rights over mineral development, for example, can be seen as an appropriate form of redress for damages suffered by the ancestors of modern Aborigines at the hands of the predecessors of modern miners. One authority has noted, for example, that "[o]f all forms of European economic activity mining was probably the most devastating in its effects on resident Aborigines." 146

Apart from arguments based on fairness to Aborigines, and looking back to the experience in the United States in the 'split-estate' situation, the last few decades have seen the flourishing of a seemingly inexorable trend - away from the notion that the miner has an absolute right to explore for and develop mineral deposits and toward the notion that the surface owner has a substantial say in the matter, in some cases reaching an absolute right of veto. It might be argued that in most situations, this has occurred without a careful weighing of the economic trade-offs, without asking which approach would maximise society's wealth. In most if not all such situations, relative economic advantage, measured in ordinary terms, will favour miners over all others. ${ }^{147}$ In the Northern Great Plains, for example, it seems quite clear that coal development makes a greater contribution to national wealth than ranching, at least when measured by conventional economic standards, yet Congress voluntarily granted the ranchers a veto.

One might bemoan this trend as an unwarranted de-emphasis of the wealth a thriving minerals industry can produce, ${ }^{148}$ but it is difficult to

146 The Otherside of the Frontier, note 120 supra, 153.

147 See e.g. Report of the Inquiry, note 130 supra, 250-251.

148 For the expressed position of the Australian mining industry on the questions addressed here, see Australian Mining Industry Council, Aboriginal Affairs Policy Statement (1982), published as Appendix 9.1 in Cousins and Nieuwenhuysen, Aboriginals and the Mining Industry, note 2 supra, 169; H.N. Morgan, "The Mining Industry and Aborigines", in Aboriginal Sites, Rights and Resource Development, note 113 supra, $f f$. 
deny the existence of the trend, and to disclaim its relevance to arriving at a sensible accommodation of interests in addressing Aboriginal land rights. Taking the very long view, this trend may simply be a reflection of the transition from an industrial to a post-industrial society. The industrial revolution created demand for many minerals, including fossil fuels and many metals, and fostered a preoccupation with material wealth. Post-industrial society might be said to de-emphasise material goods, to lessen (or at least reduce the rate of growth in) demand for minerals, and to increase the value assigned to more intangible qualities associated with land.

From this perspective, the trend toward greater deference to surface uses threatened by mineral development springs from impulses similar to those giving rise to the trend toward greater recognition of the land claims of indigenous peoples. The trends share other characteristics as well. Both have spilled beyond national boundaries, both tend to generate strong emotions, and both are inextricably bound up in, and tend to be expressed in terms of legal principles and rights. But it is easy to make too much of such similarities, for major differences exist between the issues. The indigenous peoples' land claims raise more profound questions of morality and the always sensitive issue of race and bring much more directly into play the entire historical experience of contact between different cultures. Still, it is scarcely surprising that where these trends intersect, their combination seems to have a synergistic effect, increasing the amount of controversy and conflict geometrically over what each would separately produce.

In the larger context of Aborigines' struggle for land rights, one final, perhaps uncomfortable question must be posed: is the game worth the candle - is the controversy sparked by the effort to gain control over mineral activity worth the advantages such control offers to Aborigines? Currently, the most important opponent of expanded Aboriginal land reserves is the mining industry, and the nub of its opposition seems to be concern over loss of access to such reserves. Though the industry is also naturally concerned about financial burdens flowing from royalty or compensation arrangements with Aborigines, a question closely related to access, conversations with several knowledgeable Australians leave me with the distinct impression that access is generally more important than money to the industry.

If Aborigines had no absolute veto over access, the industry would have considerably less reason to oppose new or larger Aboriginal land reserves. Thus, as suggested earlier, Aboriginal groups collectively might be regarded as confronting a choice between a larger degree of control over mining in smaller land areas, and more limited control over larger areas.

Moreover, at least the more progressive members of the mining industry are - whether motivated by concern with their public image or by a genuine commitment to protection - manifesting increased 
sensitivity to the disruptive effects of mineral activity on sites held sacred by Aborigines. This sensitivity suggests that so long as protection of such sites does not substantially defeat industry access to areas of high mineral interest, some compromise and accommodation might be possible between Aboriginal communities and the industry. ${ }^{149}$ On the other hand, optimism may be tempered by one anthropologist's observation that it is "not a facetious question" to ask whether all of Australia is a sacred site to Aborigines. ${ }^{150}$

Third, under practically all the solutions offered by the disputants, the government itself would retain the power to withhold areas from industry access. Though it is hazardous to predict the willingness of the government to wield such a tool (and to date Australian governments have had, at best, a mixed record even when Aboriginal groups have been strongly opposed to mining), the possibility of government denial of access is another lever for bargaining aimed at achieving a mutually acceptable accommodation between industry and Aboriginal groups.

These factors suggest that, even without an Aboriginal veto, Aboriginal land reserves may be protected against at least some significantly disruptive mining activity. Further, the American Indian experience shows that a veto over mining is not a panacea for the myriad of disadvantages American Indians encounter. Some tribes have used the control the veto provides to considerable advantage, while others have not. There is no reason to expect Indians, or Aborigines for that matter, to be any less susceptible to the bad judgments that one encounters in all commercial decision making.

On the other hand, the level of protection for Aboriginal interest provided by the factors outlined above may remain unacceptable to Aborigines, and the alternative of larger land reserves without a veto illusory. The existence of veto would, moreover, seem to improve the Aboriginal bargaining position over financial and other arrangements that hold promise to advance Aboriginal interests. Finally, so long as non-Aboriginal farmers and pastoralists in Western Australia retain their veto, denial of similar rights to Aborigines will naturally be perceived as a signal of second class status.

Despite these reasons for pessimism, the fact remains that, so long as the Australian courts remain aloof from the basic questions of Aboriginal land rights under the common law, the Aboriginal case for a veto will be won or lost at the bar of public opinion, expressed through elected representatives. Given the deep divisions that currently exist, it may be many years before a solution that can command widespread support will be reached. In the United States, final resolution has involved a complex interplay among moral, legal and political principles as well as among governmental institutions, even though

149 See e.g. Seaman Report, note 4 supra, 163-164, 178-179.

150 Maddock, note 79 supra, 131. 
native claim resolution has been almost exclusively the function of the national government. In Australia, because the issue has so far mostly been dealt with by the separate states, its resolution could become even more tangled.

In the end, the American experience set forth in this paper suggests that a solution can be found. Though the circumstances that have prevailed in the United States are sufficiently different to temper one's optimism, and though the United States is perhaps less stridently utilitarian and more accustomed to responding to claims couched in the language of rights, ${ }^{151}$ perhaps reflection on that experience can, in some small way, help advance the understanding necessary to achieve a solution to the current Australian dilemma.

151 See Hugh Collins, "Political Ideology in Australia" and Nicholas Jose, "Cultural Identity" in The Daedalus Symposium, note 107 supra, 161, 336-337. 